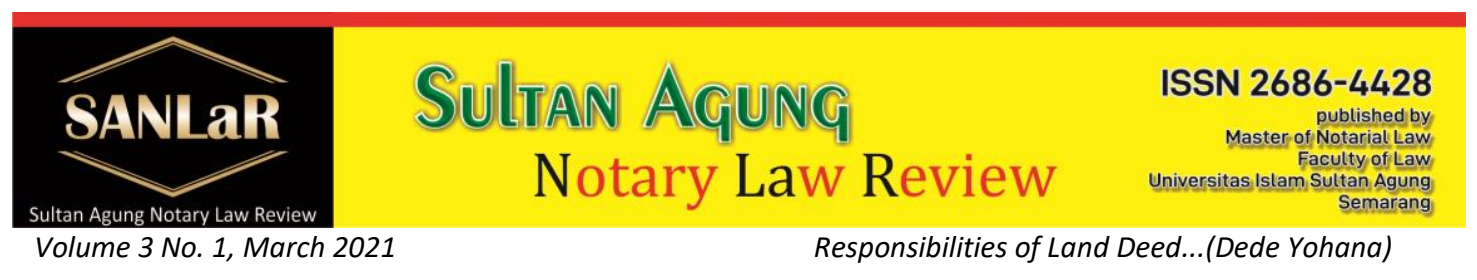

\title{
Responsibilities of Land Deed Making Officials (PPAT) for Preparing Unsettled Land Deeds of Sale and Purchase
}

\author{
Dede Yohana *) \\ *) Student of Master of Notary Law, Faculty of Law, Universitas Islam Sultan \\ Agung Semarang, E-mail : dedeyohana@gmail.com
}

\begin{abstract}
The purpose of this study is to identify and analyze: 1). Arrangements for the transfer of land rights in the Sale-Purchase Deed made before the PPAT. 2). Position of the Deed of Sale and Purchase, which payment has not been fully paid. 3). PPAT responsibility for the preparation of the Sale and Purchase Deed, the payment of which has not been fully paid. The approach method in this research is juridical normative, namely research that emphasizes the science of law and tries to examine the rules of law that apply to the subject matter. The data used are primary and secondary data obtained through interviews and literature studies, while the data analysis method is carried out by qualitative descriptive analysis. The results of the research resulted in the following conclusions: 1) The PPAT of the Official for Making Land Deeds is appointed by the government, in this case the National Land Agency with certain duties and authorities in the transfer of land rights, deeds of assignment of land rights, and deeds of granting power to impose mortgage rights as regulated in the prevailing laws and regulations. PPAT has responsibility for the deed it makes, namely administrative responsibility, civil responsibility and criminal responsibility. 2). Whereas if the PPAT has been negligent either intentionally or unintentionally made a Sale and Purchase Deed even though the land payment has not been paid off so that it is detrimental to the PPAT client, then the PPAT will be liable administratively and can also be sued to be accountable for its negligence in civil terms. 3). Efforts made by the Official for Making Land Deeds (PPAT) if the payment for the sale and purchase of land has not been paid off is by making a Sale and Purchase Agreement (PPJB). The land sale and purchase agreement was made because one of the conditions for the implementation of the Land Sale and Purchase Deed had not been fulfilled, namely the payment of land which had to be paid in full according to the agreed price. After paying off the remaining payment, then a Sale and Purchase Deed can be made.
\end{abstract}

Keywords: Responsibility of PPAT; Deed of Sale and Purchase; Transfer of Land.

\section{Introduction}

PPAT has an important role in the process of transferring land rights. This is as contained in Article 1 of Government Regulation (PP) Number 37 of 1998 as amended by Government Regulation (PP) Number 24 of 2016 which states that PPAT is a public official who is given the authority to make authentic deeds regarding certain legal actions regarding rights. over land or ownership rights over apartment units. An engagement can be born in 2 (two) ways, namely 
either because of approval or because of the law, this is as stated in Article 1233 of the Civil Code which states that "Every engagement is born either because of consent, either because of the law."

PPAT has a main role, namely organizing the registration of land rights or Property Rights to Apartment Units, which will be used as the basis for registering changes to land registration data as a result of this legal act. The legal actions referred to in the authority of PPAT are regulated in Article 2 of Government Regulation Number 37 of 1998, one of which is regarding Sale and Purchase. The sale and purchase agreement has an essential element, namely the existence of an object and a price. ${ }^{2}$ This element is an absolute element that must be present at the time of sale and purchase to be carried out, without this element the agreement will lose its main character. In carrying out the Sale and Purchase, it must be carried out in cash and in light. Cash in the sense that payment for the object to be transferred must be carried out immediately as well as the delivery of the purchased item must be done clearly / clearly, so that fraud will be avoided. A sale-purchase is deemed to have occurred when the agreement regarding the price and the object has occurred even though the delivery of the object which is the object of the sale has not been fulfilled.

The existence of a Notary is a public official who is authorized to make authentic deeds and has other powers as referred to in law or based on other laws. The Notary Institution itself entered Indonesia at the beginning of the 17th century with the existence of Vereenigde Oost Ind. Compagnie (VOC) in Indonesia. ${ }^{3}$ Whereas the Land Deed Making Officials began to be recognized based on the Decree of the Minister of Agrarian Affairs and Spatial Planning / Head of the National Land Agency Number 112 / KEP-4.1 / IV / 2017 and the association of organizations for PPATs established on September 24, 1987 was recognized as a legal entity (rechtpersoon) based on Decree of the Minister of Justice on April 1, 1989 Number C2-3281.HT.01.03.Th.89.12 ${ }^{4}$ However, in certain circumstances, notaries may refuse to provide services for certain reasons (Article 16 paragraph [1] letter d UUJN). In his authority to make authentic deeds, for example, a sale and purchase deed, a Notary must be able to formulate the wishes of the parties and remain based on the prevailing regulations, so as not to cause disputes or problems in the future, for example problems related to the sale and purchase of a plot of land between seller and buyer.

1 Siahaan, Rudy Haposan. (2017). Hukum Perikatan Indonesia Teori dan Perkembangannya, Malang : Intelegensia Media. p. 32.

${ }^{2}$ Isnaeni, H.Moch. (2016). Perjanjian Jual Beli, Bandung: Refika Aditama. p. 27.

${ }^{3}$ Adjie, Habib. (2008). Hukum Notaris Indonesia tafsir Tematik Terhadap UU No. 30 tahun 2004 tentang Jabatan Notaris, Bandung : Refika Aditama. p. 3.

4 Sulhan,dkk, (2018). Profesi Notaris dan Pejabat Pembuat Akta Tanah Panduan Praktis dan Mudah Taat Hukum, Jakarta : Mitra Wacana Media. p. 137. 
In the initial process of the sale and purchase of a plot of land and an agreement has been signed, the parties will delegate to the PPAT to make a sale and purchase deed which will then be used as completeness in making a land certificate. However, it turns out that if the PPAT is not careful about the buyer's obligations, the notary will make a sale-purchase deed, what happens is after the deed has been made, but in fact the settlement has not yet been made, this is a concern for the accuracy of the PPAT.

\section{Research methods}

Based on the background, the title was appointed: "The Effect of the Increase in the Selling Value of Tax Objects - Land and Building Tax (Njop - Pbb) on the Transfer of Land Rights at the Notary Office - PPAT in Blora Regency". This research attempts to answer problem regarding the arrangement of the transfer of land rights in the Sale-Purchase Deed made before PPAT, the position of the Sale-Purchase Deed whose payment has not been paid off, the PPAT's responsibility for the making of the Sale and Purchase Deed whose payment has not been fully paid. The approach method used in this research is normative juridical. Normative juridical, namely research that emphasizes the science of law and tries to examine the rules of law that apply to the subject matter. ${ }^{5}$ The research specification used is descriptive analytical. Primary data collection was carried out by interview method. This type of interview used in this study using free guided interviews, is a combination of free and guided interviews. ${ }^{6}$ Secondary data is data obtained from a review of the literature or a review of various literature or related library materials.

\section{Results and Discussion}

\subsection{Regulation of the Responsibilities of Land Deed Making Officials (PPAT) for Making Land Sale and Purchase Deeds}

After the entry into force of the Basic Agrarian Law (UUPA) on September 24, 1960 , the period of dualism of land law in effect in Indonesia, namely customary law and western law, ended. With the enactment of the UUPA, land rights that were in effect at that time, both previously regulated in Customary Law and Western Law, were converted into one of the new rights under the UUPA. Therefore, there is not only the unification of the Agrarian Law but the unification (unity) of land rights. With the creation of unification in the land sector in our country, it gives a new meaning to Agrarian Law because it is based on one legal system, namely the National Agrarian Law. ${ }^{7}$ Based on Government

\footnotetext{
5 Mamadji, Soerjono Soekanto and Sri. (2009). Penelitian Hukum Normatif: Suatu Tinjauan Singkat, Jakarta : Raja Grafindo Persada. p.1.

${ }^{6}$ Ibid, p. 84

7 Harsono, Boedi. (2003). Hukum Agraria Indonesia, Sejarah Pembentukan UUPA, Isi dan Pelaksanaannya, Jakarta : Djambatan. p. 58.
} 
Regulation Number 24 of 1997, the transfer of land and objects on it is carried out by means of a PPAT deed. The transfer of land from the owner to the recipient is accompanied by juridical surrender (juridische levering), namely the handover that must meet the formalities of the law, including the fulfillment of requirements; carried out through a predetermined procedure; using documents; made before the PPAT. ${ }^{8}$

PPAT deed is an authentic deed that has absolute power regarding matters or events mentioned in the deed, so what is proven is the event. ${ }^{9}$ The obligation to submit proof of title to land that is sold is very important because Article 1482 of the Civil Code states "the obligation to deliver an item includes everything that is its equipment and is intended for its permanent use, along with certificates of ownership, if any". So, handing over a plot of land includes submitting the certificate. The transfer of land rights from the owner to the recipient is accompanied by a juridical transfer (juridische levering), is a handover that must meet the formalities of law, including fulfillment of requirements, carried out through a predetermined procedure, using documents, made by / before the PPAT. ${ }^{10}$ In Government Regulation Number 37 of 1998 concerning the position regulations for Land Deed Making Officials formulates "Land Deed Making Officials are public officials authorized to make authentic deeds ..." the words make are interpreted in a broad sense (verlijden), namely producing deeds in the form prescribed by law. The law includes preparing, compiling and making deeds in accordance with the prescribed form. ${ }^{11}$ Examples of violations that often occur in the practice of making PPAT deeds are: ${ }^{12}$

1. Sign the sale and purchase deed before a clean check / certificate check is carried out at the National Land Agency Office

2. Just do a verbal check

3. The sale and purchase deed is not read out by PPAT in detail but only explains the contents of the deed in an outline

4. The parties are not signed on to the sale and purchase deed simultaneously

5. The witnesses were never directly involved in a process of signing the deed

6. Receiving work from colleagues, but the deed to be made has been previously signed by the parties;

7. The transaction price value stated in the sale and purchase deed is different from the actual transaction value

\footnotetext{
${ }^{8}$ Muhammad, Abdul Kadir. (1994). Hukum Harta Kekayaan, Cetakan I, Bandung: Citra Aditya Bakti. p.55.

${ }^{9}$ Sutedi, Adrian. (2012). Sertifikat Hak Atas Tanah, Jakarta: Sinar Grafika. p.127.

${ }^{10}$ Muhammad, Abdul Kadir. op.cit, p. 55.

${ }^{11}$ Abdurrahman. (2008). "Kedudukan Hukum Akta PPAT Sebagai Alat Bukti". Media Notariat. p. 71.

12 Prawira, I Gusti Bagus Yoga . Tanggungjawab PPAT terhadap Akta JuaL Beli Tanah, Universitas Mataram, Jurnal IUS, Vol IV Nomor I, April 2016. p. 68.
} 
8. The Sale and Purchase Deed has been drawn up even though the payment for the sale and purchase of the land has not been fully paid.

If a PPAT deed is issued which is legally flawed because of the PPAT's negligence or deliberate PPAT itself, the PPAT must provide accountability both morally and legally. The causes of problems can arise directly as a result of PPAT negligence, or can also arise indirectly if it is done by someone else. Thus, for this matter, PPAT can be held accountable in connection with the Sale and Purchase Deed which it has made has been canceled or declared null and void by the Court Decision as a result of finding a legal flaw in its making both administratively, civil and criminal if the PPAT concerned is found guilty in the manufacturing procedure. The Sale and Purchase Deed. Jjj

As for the PPAT's responsibility for deeds that contain legal flaws, it can be described as follows;

1. Administrative responsibility

Administrative errors or commonly referred to as administrative malls carried out by PPAT in carrying out some of the activities of land registration and transfer will certainly have legal consequences, namely that PPAT can be held accountable. ${ }^{13}$ Whereas PPAT is responsible for drawing up sale and purchase deeds that contain legal flaws. A PPAT that makes a land sale and purchase deed containing this legal flaw, is categorized as an act of abuse of authority, given that the existing authority under Article 2 PJPPAT has been misused, so that the use of that authority is ultimately not in accordance with the purpose of granting the authority itself, in the event This appears to have been an abuse of authority by the PPAT because it does not exercise its authority properly. ${ }^{14}$

PPAT's responsibility regarding intentional, negligent and / or negligent in the making of the sale and purchase deed which deviates from the formal requirements and the material requirements for the procedure for making a PPAT deed, then the PPAT may be subject to administrative sanctions. ${ }^{15}$ Based on the case of BPN 1/2006, deviation from the formal and material requirements is a serious violation by the PPAT which may be subject to a sanction of dishonorable dismissal from his position by the Head of the Indonesian National Land Agency.

2. Responsibility in civil terms

PPAT's responsibility regarding gaps, negligence and / or negligence in making sale and purchase deeds that deviate from the formal requirements and the material requirements for making PPAT deeds, not only can be subject to administrative sanctions but also does not preclude the possibility of being sued for compensation by parties who feel aggrieved.

\footnotetext{
13 A.P, Parlindungan. (2009). Pendaftaran Tanah Di Indonesia berdasarkan PP No.24 Tahun 1997, Bandung : Mandar Maju. p. 155.

${ }^{14}$ Winarsi, Sri. (2002). "Pengaturan Notaris dan PPAT sebagai Pejabat Umum", Majalah Yuridika, Fakultas Hukum Universitas Airlangga, Volume 17 No.2, Surabaya, March. p. 125.

${ }^{15}$ H.R, Ridwan. (2006). Hukum Administrasi Negara, Jakarta : Raja Grafindo Persada. p. 132.
} 
In connection with the error (oepsfout) of the PPAT, it must be examined regarding the form of the error, namely whether the error is a defaultoracts against the law (onrechtmatige daad). The general opinion is that, default occurs if it is preceded by an agreement, whereas if it is not related to the agreement, the form of violation is called an unlawful act or onrechtmatige daad. Based on these general principles, the authors assume that PPAT actions that have caused a deed to be legally flawed can be considered as an illegal act, considering that between PPAT and the client or party involved in the deed there has never been an agreement.

In determining that a bandage can qualify as breaking the law, 4 conditions are needed: ${ }^{16}$

a. Contrary to the legal obligations of the perpetrator;

b. Contrary to the subjective rights of others;

c. Contrary to decency;

d. Contrary to propriety, thoroughness and prudence.

For the existence of an unlawful act, the four criteria are not required cumulatively, but the fulfillment of one of the criteria alternatively is sufficient to fulfill the requirements for an act of breaking the law. Civil sanctions imposed on the PPAT for acts violating the law (onrechtmatige daad), namely actions that cause harm, and normatively these acts are subject to the provisions of Article 1365 of the Civil Code, which reads "Every act that violates the law, which incurs losses to others, obliges people who because of his fault published the loss, compensates for the loss". ${ }^{17}$

Thus as a result of deliberate or negligent errors in the form of carelessness, inaccuracy and inaccuracy in the implementation of legal obligations for the PPAT in making land sale and purchase deeds, causing one's subjective implementation to be disturbed, if it causes loss to the parties, then The PPAT concerned must be responsible for compensating the losses suffered by the parties in the form of compensation, compensation and interest. The determination that the deed only has legal force under the hands of or is declared null and void and / or is an offense for an unlawful act that causes loss, must be based on the existence of a court decision that has permanent legal force, ${ }^{18}$

3. Liability criminally

The imposition of criminal sanctions against PPAT can be carried out as long as a PPAT has made a fake letter or falsified a deed with the qualifications as a criminal act.

\footnotetext{
${ }^{16}$ Agustina, Rosa. (2003). Perbuatan Melawan Hkum, Pasca Sarjana FH Universitas Indonesia. p. 117.

17 Yahya, Harahap, M. (2005). Hukum Acara Perdata : gugatan, Persidangan, Penyitaan, Pembuktian, dan Putusan Pengadilan, Jakarta : Sinar Grafika. p. 167.

${ }^{18}$ Mashudy, Hermawan. (2007). Dasar-dasar Hukum Pembuktian, Surabaya : UMSurabaya. p. 65.
} 
Based on the description above, it can be concluded that a PPAT cannot be subject to Article 266 paragraph (1) of the Criminal Code. This is because in Article 266 paragraph (1) there is an element of ordering PPAT in making sale and purchase deeds only as a medium (tool) for the birth of an authentic deed, while the initiative arises from the parties so that in this case the PPAT is the party ordered not the party who ordered. However, if a PPAT has deliberately and is acknowledged or realized that he is cooperating with the perpetrator, the PPAT may be subject to Article 263 paragraph (1) of the Criminal Code which is linked to Article 55 (1), namely participating in a criminal act. In addition, because the products produced by the PPAT are subject to a weighting as regulated in Article 264 paragraph (1) letter a of the Criminal Code in conjunction with Article 55 paragraph (1) of the Criminal Code.

\subsection{Implementation of the Responsibility of Preparing Land Deeds (PPAT) for Preparing Unsettled Land Deeds of Sale and Purchase}

The Official for Making Land Deeds (PPAT) is responsible to the parties, because of the illegal actions committed by PPAT in carrying out their duties, causing losses to the parties requesting their services. The form of PPAT's responsibility when it is related to its profession adheres to the principle of fault responsibility (based on fault of liability). So that in making authentic deeds, PPAT must be responsible if there is an error or violation of the deed it makes. However, if the element of error or violation occurs on the part of the parties, then the PPAT concerned cannot be held accountable, because PPAT only records what is conveyed by the parties or the parties to be recorded in the deed. ${ }^{19}$

In this case, PPAT only regulates what happened, what the parties saw and said, then PPAT poured it into a deed. So that if there is an error made by PPAT, whether on purpose or due to negligence, it has misused the authority of PP 37 of 1998 so that it causes people to suffer losses, and if the mistake can be proven by the party who feels aggrieved, then the PPAT can be subject to sanctions in accordance with the provisions of the Prevailing Law.

For this reason, the Official for Making Land Deeds must also pay close attention to the process of stages that must be carried out, both formal and material provisions in making the sale and purchase deeds that meet the requirements. ${ }^{20}$ Administrative sanctions imposed by PPAT for violating Article 11 paragraph (1), Article 13 paragraph (2), and Article 15 paragraph (1) of Act No. 4 of 1996 concerning Mortgage Rights to Land along with objects related to Land, and in accordance with Article 6 paragraph (1) of the IPPAT Code of Ethics, Article 23 paragraph (1) can be in the form of sanctions, namely 1 )

\footnotetext{
${ }^{19}$ Mamminanga, Andi. (2008). Pelaksanaan Kewenangan Majelis Pengawas Notaris Daerah dalam Pelaksanaan Tugas Jabatan Notaris berdasarkan UUJN, Tesis, Fakultas Hukum Universitas Gajah Mada. p. 32.

${ }^{20}$ Mustofa. (2010). Tuntunan Pembuatan Akta-Akta PPAT, Yogyakarta : Karya Media. p. 95.
} 
Warning; 2) Warning; 3) Schorsing of IPPAT membership; 4) Termination from IPPAT membership; 5) Disrespectful termination of IPPAT membership. ${ }^{21}$

The PPAT action is an act that does not provide legal protection to the parties in the sale and purchase agreement, and the process of transferring rights to land, in principle, is that as long as the rights and obligations of the seller and buyer in the sale and purchase have been fulfilled in accordance with Article 52; Article 53, and Article 54 CLIENTIFICATION; the legal terms of the sale and purchase agreement in accordance with Article 1320 of the Civil Code, as well as the fulfillment of the three provisions stipulated by customary law, namely cash, real, and light. ${ }^{22}$ The forms of obligations and rights of both the seller and the buyer that need to be carried out by each party, in carrying out the buying and selling process. ${ }^{23}$

Civil sanctions are imposed on the PPAT if the actions committed cause harm, and are normatively subject to the provisions of Article 1365 of the Civil Code. However, if the implementation of the duties and positions of the deed contains a legal flaw, then a court decision is declared inauthentic, because it does not meet the formal and material requirements, so that the power of the deed is only under hand, and will result in difficulties for the parties or persons entitled to the deed. It to exercise their rights guaranteed by law, namely the right to use the deed as evidence of legal rights; postulate their rights, deny the rights of others.

\subsection{Efforts Made By Officials Making Land Deeds (PPAT) If The Payment For The Sale And Purchase Of Land Has Not Paid Off}

Efforts made by the Official for Making Land Deeds (PPAT) if the payment for the sale and purchase of land has not been paid off is by making a Sale and Purchase Agreement (PPJB). The land sale and purchase agreement was made because one of the conditions for implementing the Deed of Sale and Purchase of land had not been fulfilled, namely the payment of land which had to be paid in full according to the agreed price. In the land sale and purchase agreement, it is explained that the Buyer has not been able to pay the price of the land to the Seller, so the Buying Party binds the sale and purchase of the land by giving a plot of money or a down payment of a certain value then the remaining payment is paid within a specified period. After paying off the remaining payment, then a Sale and Purchase Deed can be made. The PPJB is made to carry out a temporary binding before the making of an official AJB in the presence of the Official for Making Land Deeds (PPAT). In general, the contents of the PPJB are the seller's agreement to bind himself to sell to the buyer, accompanied by a sign or advance based on the agreement. In general, PPJB is made under hand for some reason, such as the payment of the price has not

\footnotetext{
${ }^{21}$ Abdurrahman, (2008). Kedudukan Hukum Akta PPAT Sebagai Alat Bukti. Media Notariat, p. 88.

22 Loc. cit.

${ }^{23}$ Urip, Santoso. (2010). Pendaftaran Dan Peralihan Hak Atas Tanah , Jakarta : Kencana. p. 86.
} 
been fully paid. The PPJB contains agreements, such as the amount of the price, the time for repayment and the making of the AJB. ${ }^{24}$

In 2011, the implementation of this PPJB was contained in Act no. 1 of 2011 concerning the Preliminary Agreement System for Sale and Purchase of Houses, which allows for a preliminary agreement related to sale and purchase transactions for objects of houses or flat (flats), it is even confirmed by SEMA No. 4 of 2016 which states that PPJB can occur if in a condition there is a full payment from the buyer and there is control over the object. And in 2019, the government issued PUPR Regulation No. 11 / PRT / M / 2019 as a complement to the previous PPJB provisions. ${ }^{25}$

The existence of this PPJB has an important role as an initial effort before the existence of AJB. With the PPJB, it does not prevent the parties from transacting, although in practice at the time of signing the PPJB there was no transfer of land rights due to several considerations because for the transfer to occur, it must go through AJB, and this PPJB is the "entry point" to AJB. PPJB is intended to bind between the seller and the buyer, which is generally done by the developer to make it easier for buying and selling property transactions. PPJB which is a preliminary agreement, the function of this PPJB is basically to prepare the main agreement / principal agreement that will be carried out, in this case the Sale and Purchase Deed (AJB). ${ }^{26}$

In practice, there are 2 (two) types of PPJB, namely PPJB paid off and PPJB not paid off. The differences between the two are:27

a. PPJB paid off

1) There is a power clause;

2) The buyer must obtain absolute power to guarantee the implementation of the buyer's rights in the sale and purchase transaction and it will not end for any reasons;

3) This agreement will not be canceled due to the death of one of the parties, but it is decreasing and continues to apply to the heirs.

b. PPJB is not paid off

There is a clause regarding the condition if the sale and purchase is canceled in the middle of the road (for example: the buyer cancels the purchase, etc.).

The general official authorized in making PPJB and AJB is different, where for PPJB it is made before a Notary, while for AJB it is made before the local PPAT, so that the forms of PPJB and AJB are in the form of an authentic deed which

\footnotetext{
${ }^{24}$ Loc.cit.

${ }^{25}$ Amasangsa, Made Ara Denara Asia. (2009). I Made Dedy Priyatno, Perjanjian Pengikatan Jual Beli (PPJB) dalam Transaksi Peralihan Hak Atas Tanah dan /atau Bangunan, Universitas Udayana. p. 43.

${ }^{26}$ Loc. cit.

${ }^{27}$ Amin Purnawan, Dewi Kurnia Putri. (2017). Perbedaan Perjanjian Pengikatan Jual Beli Lunas Dengan Perjanjian Pengikatan Jual Beli Tidak Lunas, Jurnal Akta Vol. 4 No. 4 December 2017. p. 76.
} 
has perfect evidentiary power unless it can be proven otherwise. The principle used at the time of making the PPJB is the principle of freedom of contract (contractvrijheid) because the Notary will make the PPJB deed according to what the parties want, without ruling out that the parties will fully surrender to the Notary regarding the contents of the PPJB. With the existence of the principle of freedom of contract, such freedom has limitations, namely that it does not conflict with statutory regulations, morals and public order.

\section{Closing}

\subsection{Conclusion}

1. Whereas the PPAT of the Official for Making Land Deeds is appointed by the government, in this case the Land Agency, in order to serve the needs of the community for deeds of transfer of land rights, deeds of assignment of land rights, and deeds of granting power to impose mortgage rights as regulated in the prevailing laws and regulations. In line with the duties and authorities possessed by the PPAT, the PPAT has responsibility for the deed it makes, namely administrative responsibility, civil responsibility and criminal responsibility;

2. Whereas if the PPAT has been negligent either intentionally or unintentionally made a Sale and Purchase Deed even though the land payment has not been paid off so that it is detrimental to the PPAT client, the PPAT will be liable administratively and can also be sued to be accountable for his negligence on a civil basis

3. Efforts made by the Official for Making Land Deeds (PPAT) if the payment for the sale and purchase of land has not been paid off is by making a Sale and Purchase Agreement (PPJB). The land sale and purchase agreement was made because one of the conditions for implementing the Deed of Sale and Purchase of land could not be fulfilled, namely the payment of land which must be paid in full according to the agreed price. In the land sale and purchase agreement, it is explained that the Buyer has not been able to pay the price of the land to the Seller, so the Buying Party binds the sale and purchase of the land by giving a plot of money or a down payment of a certain value then the remaining payment is paid within a specified period. After paying off the remaining payment, then a Sale and Purchase Deed can be made.

\subsection{Suggestion}

1. That the PPAT should have dexterity and expertise as well as accuracy before making a deed that is detrimental to a party;

2. If the payment for the sale and purchase of the land has not been paid off, then the PPAT should not rush into making a Sale and Purchase Deed. 


\section{References}

Books:

[1] Abdul Kadir Muhammad. (1994). Hukum Harta Kekayaan, Cetakan I, Bandung: Citra Aditya Bakti.

[2] Abdurrahman. (2008). Kedudukan Hukum Akta PPAT Sebagai Alat Bukti. Media Notariat.

[3] Adrian Sutedi. (2012). Sertifikat Hak Atas Tanah, Jakarta: Sinar Grafika.

[4] Andi Mamminanga. (2008). Pelaksanaan Kewenangan Majelis Pengawas Notaris Daerah dalam Pelaksanaan Tugas Jabatan Notaris berdasarkan UUJN, Tesis, Yogyakarta : Fakultas Hukum Universitas Gajah Mada.

[5] Boedi Harsono. (2003). Hukum Agraria Indonesia, Sejarah Pembentukan UUPA, Isi dan Pelaksanaannya, Jakarta : Djambatan.

[6] Dewi Kurnia Putri, Amin Purnawan. (2017). Perbedaan Perjanjian Pengikatan Jual Beli Lunas Dengan Perjanjian Pengikatan Jual Beli Tidak Lunas, Jurnal Akta Vol. 4 No. 4 December 2017.

[7] H.Moch. Isnaeni. (2016). Perjanjian Jual Beli, Bandung : Refika Aditama.

[8] Habib Adjie. (2008). Hukum Notaris Indonesia tfsir Tematik Terhadap UU No. 30 tahun 2004 tentang Jabatan Notari , Bandung : Refika Aditama.

[9] Harahap, M. Yahya. (2005). Hukum Acara Perdata : gugatan, Persidangan, Penyitaan, Pembuktian, dan Putusan Pengadilan, Jakarta : Sinar Grafika.

[10] Hermawan, Mashudy. (2007). Dasar-dasar Hukum Pembuktian, Surabaya: UMSurabaya.

[11] I Gusti Bagus Yoga Prawira, Tanggungjawab PPAT terhadap Akta JuaL Beli Tanah, Universitas Mataram, Jurnal IUS, Vol IV Nomor I, April 2016

[12] Made Ara Denara Asia Amasangsa. (2009). I Made Dedy Priyatno, Perjanjian Pengikatan Jual Beli (PPJB) dalam Transaksi Peralihan Hak Atas Tanah dan/atau Bangunan, Universitas Udayana.

[13] Mustofa. (2010). Tuntunan Pembuatan Akta-Akta PPAT, KaryaMedia, Yogyakarta.

[14] Parlindungan, A.P. (2009). Pendaftaran Tanah Di Indonesia berdasarkan PP No.24 Tahun 1997, Bandung : Mandar Maju. 
[15] Ridwan H.R. (2006). Hukum Administrasi Negara, Raja Grafindo Persada, Jakarta

[16] Rosa Agustina. (2003). Perbuatan Melawan Hkum, Pasca Sarjana FH Universitas Indonesia

[17] Rudy Haposan Siahaan. (2017). Hukum Perikatan Indonesia Teori dan Perkembangannya, Malang : Intelegensia Media.

[18] Santoso, Urip. (2010). Pendaftaran Dan Peralihan Hak Atas Tanah , Jakarta : Kencana.

[19] Soerjono Soekanto dan Sri Mamadji. (2009). Penelitian Hukum Normatif: Suatu Tinjauan Singkat, Jakarta: Raja Grafindo Persada.

[20] Sri Winarsi, (2002). "Pengaturan Notaris dan PPAT sebagai Pejabat Umum", Majalah Yuridika, Fakultas Hukum Universitas Airlangga, Volume 17 No.2, Surabaya, March.

[21] Sulhan,dkk, (2018). Profesi Notaris dan Pejabat Pembuat Akta Tanah Panduan Praktis dan Mudah Taat Hukum, Jakarta : Mitra Wacana Media. 